\title{
Analisa Ekonomi Atas Hukum Pidana terhadap Penanggulangan Tindak Pidana Korupsi
}

\author{
Dedy Syaputra ${ }^{1}$ \\ Universitas Batanghari Jl. Slamet Riyadi Broni Kota Jambi (0741) 65351 \\ Gmail : dedysyaputra83@gmail.com
}

\begin{abstract}
Abstrak. Kehidupan dimasyarakat tidak akan jauh dari permasalah ekonomi, maka permasalahan ekonomi pun akan menjadi permasalahan hukum jika aspek pemenuhan kebutuhan sehari hari mengalami kekurangan. Maka akan timbul permasalahan criminal seperti pencurian, dan lain-lain. Bahkan dalam skala yang lebih besar dapat timbulnya kejahatan kerah putih atau white collar crime. Tujuan penelitian ini bertujuan untuk menganalisis ekomomi atas hukum, atau yang umumnya di kenal sebagai "Economic Analysis of Law" akan menguji secara sistemik bagaimana orang bertindak melawan insentif-insentif hukum dan menganalisanya menurut ukuran-ukuran kesejahteraan social. Metode yang digunakan adalah pendekatan yuridis normatif yaitu untuk menemukan kaidah-kaidah dan norma hukum pidana terhadap penangulangan tindak pidana korupsi.
\end{abstract}

Kata Kunci : Analisis Ekonomi Atas Hukum Pidana, Tindak Pidana Korupsi

Abstract. Life in the community will not be far from economic problems, so even economic problems will become a legal problem if the aspect of fulfilling daily needs suffers. Then criminal problems will arise such as theft, and others. Even on a larger scale can the white collar crime arise. The purpose of this study aims to analyze economics of law, or commonly known as "Economic Analysis of Law" will test systemically how people act against legal incentives and analyze them according to social welfare measures. The method used is a normative juridical approach, which is to find the legal norms and norms for dealing with corruption.

Keywords: Economic Analysis of Criminal Law, Corruption Crime

\section{PENDAHULUAN}

Ilmu hukum merupkan suatu cabang ilmu untuk membahas hukum dari segala aspeknya. Namun demikian Ilmu hukum tetap berada pada karakternya yaitu Sui Generis ${ }^{2}$. Oleh karena itu, apapun kajian ilmu hukum dan apapun pendekatan yang digunakan dalam ilmu hukum, outputnya adalah ilmu hukum itu sendiri. Baik melalui pendekatan dogmatik atau melalui pendekatan sosiologis bahkan melalui pendekatan socio legal studies.

Dikatakan di awal bahwa ilmu hukum adalah bersifat sui generis atau ilmu yang berdiri sendiri.Walaupun demikian hukum itu sendiri merupakan alat pengendalian social yang secara sosiologis berarti berhubungan dengan unsur-unsur social, fenomena social yang terjadi di masyarakat.Sehinnga hukum pun tidak jauh dari sgala sesuatu yang terjadi di masyarakat itu sendiri.

Kehidupan dimayarakat tidak akan jauh dari permasalah ekonomi, maka permasalahan ekonomi pun akan menjadi permasalahan hukum jika aspek pemenuhan kebutuhan sehari hari mengalami kekuranagan. Maka akan timbul permasalahan criminal seperti pencurian, dan lain-lain. Bahkan dalam skala yang lebih besar dapat timbulnya kejahatan kerah putih atau white collar crime ${ }^{3}$.Oleh karenanya pada tahun 1960an muncul pemikiran tentang analisis ekonomi terhadap hukum ${ }^{4}$.

\footnotetext{
${ }^{1}$ Dedy Syaputra, SH,.MH,. Dosen Tetap PS Ilmu Hukum Fakultas Hukum Universitas Batanghari Jambi

${ }^{2}$ Sui generis adalah merupakan bahasa latin yang mengandung arti bahwa hanya satu untuk jenisnya sendiri. Artinya ilmu hukum bukanlah bagian dari ilmu-ilmu lainya, ilmu social maupun imu humaniora, melaikan adalah ilmunya tersendiri. Nurul Qahar, Logika Hukum, (Arus Timur;Makassar Cet. I 2014) Hlm. 28

${ }^{3}$ Kejahatan kerah Putih tau kejahatan yang dilakukan oleh orang- orang berendidikan dan berkedudukan. Biasanya melibatkan korporasi ataupun pejabat negara

${ }^{4}$ Jurnal Pendidikan IPS, Vol. 7. No. 1, Januari-Juni 2017, dalam tulisan Ady Irawan, Analisis Ekonomi Terhadap Hukum dalam Kebijakan Penegakan Hukum Pidana di Indonesia. Hlm. 1
} 
Bidang Analisis ekomomi atas hukum, atau yang umumnya di kenal sebagai "Economic Analysis of $L a w^{5}$ "yang menguji secara sistemik bagaimana orang bertindak melawan insentif-insentif hukum dan menganalisanya menurut ukuran-ukuran kesejahteraan social ${ }^{6}$.

Secara garis besar Analisis Ekonomi Atas Hukum menerapkan pendekatannya untuk memberikan sumbangan pikiran atas dua permasalahan dasar mengenai aturan-aturan hukum. Yakni analisis yang bersifat "positive" atau "descriptive", berkenaan dengan pertanyaan apa pengaruh aturan-aturan hukum terhadap tingkah laku orang yang bersangkutan (the identification of the effects of a legal rule); dan analisis yang bersifat "normative", berkenaan dengan pertanyaan apakah pengaruh dari aturanaturan hukum sesuai dengan keinginan masyarakat (the social desirability of a legal rule) $)^{7}$.

Atas paparan diatas, penulis merasa perlu untuk mengangkat permasalahan analisis ekonomi terhadap hukum dalam pertanggungjawaban tindak pidana korupsi dan contoh kasus-kasus yang Inkracht dengan mempertimbangkan Analisis ekonomi atas hukum.

\section{METODE PENELITIAN}

Pendekatan masalah yang digunakan dalam penelitian ini adalah dengan menggunakan pendekatan yuridis normatif. Pendekatan yuridis normatif adalah pendekatan yang dilakukan dengan cara mengkaji kaidah-kaidah hukum pidana, peraturan perundang-undangan, serta peraturan perundang-undangan lainnya yang relevan dengan permasalahan yang diteliti.

\section{HASIL DAN PEMBAHASAN}

\section{Konsep Analisis Ekonomi atas Hukum Pidana}

Tindak pidana atau strafbaar feit merupakan suatu perbuatan yang mengandung unsur 'perbuatan atau tindakan yang dapat dipidanakan' dan unsur 'pertanggungjawaban pidana kepada pelakunya'. Sehingga dalam syarat hukuman pidana terhadap seseorang secara ringkas dapat dikatakan bahwa tidak akan ada hukuman pidana terhadap seseorang tanpa adanya hal-hal yang secara jelas dapat dianggap memenuhi syarat atas kedua unsur itu ${ }^{8}$.

Berkaitan dalam asas hukum pidana yaitu Geen straf zonder schuld, actus non facit reum nisi mens sir $r e a^{9}$, Tindak pidana hanyalah menunjuk kepada dilarang dan diancamnya perbuatan itu dengan suatu pidana, kemudian apakah orang yang melakukan perbuatan itu juga dijatuhi pidana sebagaimana telah diancamkan akan sangat tergantung pada soal apakah dalam melakukan perbuatannya itu si pelaku juga mempunyai kesalahan. Sedangkan sebagai dasar pertanggungjawaban adalah kesalahan yang terdapat pada jiwa pelaku dalam hubungannya dengan kelakuannya yang dapat dipidana serta berdasarkan kejiwaannya itu pelaku dapat dicela karena kelakuanya itu. Dengan kata lain, hanya dengan hubungan batin inilah maka perbuatan yang dilarang itu dapat dipertanggungjawabkan pada si pelaku ${ }^{10}$.

Pertanggungjawaban pidana dalam istilah asing disebut dengan teorekenbaardheid atau criminal responsibility yang menjurus kepada pemidanaan pelaku dengan maksud untuk menentukan apakah seseorang terdakwa atau tersangka dipertanggungjawabkan atas suatu tindakan pidana yang terjadi atau tidak. Selain itu, menurut Tresya bahwa tanggung jawab ini tentunya dapat dilaksanakan dengan sebaik mungkin, tanpa mengorbankan salah satu pihak (pihak konsumen dan pelaku usaha) ${ }^{11}$.

Unsur-unsur pertanggung jawaban tindak pidana ada tiga, yaitu;

1) Mampu bertanggung jawab.

${ }^{5}$ Pemikiran ini dilatar belakangi oleh mazhab utilitarianisme yang di pelopori oleh Jeremy Bantham (1789) pemikiran ini tersebar dalam tulisan-tulisan berupa analisis atas hukum pidana dan penegakannya, analisis mengenai hak milik dan substantial treatment yang membahas tentang proses-prose hukum.Namun pemikiran ini terlambat sampai tahun 1960 an dan muncul kembali pada tahun 1990an.

${ }^{6}$ Ibid., Hlm. 1

${ }^{7}$ Ibid., Hlm. 2

${ }^{8}$ Indrianto Seno Aji, Antar Penegak Hukum dan Korupsi Sistematik Sebagai Kendala Penegak Hukum Di Indonesia,(UI, FEMM, Jakarta. 2007), hal 1

${ }^{9}$ Tidak dipidana jika tidak ada kesalahan

${ }^{10}$ Ibid., Hlm 2

${ }^{11}$ Tresya, Peran BPOM Dalam Melakukan Pengawasan Terhadap Pangan Tanpa Izin Edar, Jurnal Wajah Hukum, Volume 2 Nomor 2 (Oktober 2018)., Hlm 175. 
Pertanggungjawaban (pidana) menjurus kepada pemidanaan petindak, jika telah melakukan suatu tindak pidana dan memenuhi unsur-unsurnya yang telah ditentukan dalam undang-undang.

2) Kesalahan dianggap ada,

Apabila dengan sengaja atau karena kelalaian telah melakukan perbuatan yang menimbulkan keadaan atau akibat yang dilarang oleh hukum pidana dan dilakukan dengan mampu bertanggung jawab.

3) Tidak ada alasan pemaaf.

Hubungan petindak dengan tindakannya ditentukan oleh kemampuan bertanggungjawab dari petindak.Ia menginsyafi hakekat dari tindakan yang akan dilakukannya, dapat mengetahui ketercelaan dari tindakan dan dapat menentukan apakah akan dilakukannya tindakan tersebut atau tidak. Tiada terdapat "alasan pemaaf", yaitu kemampuan bertang gungjawab, bentuk kehendak dengan sengaja atau alpa, tiada terhapus keselahannya atau tiada terdapat alasan pemaaf, adalah termasuk dalam pengertian kesalahan.

Analisis ekonomi atas hukum membangun asumsi baru bahwa manusia secara rasional akan berusaha mencapai kepuasan maksimum bagi dirinya. Secara umum dapat dikatakan bahwa prinsip utama yang digunakan untuk memahami analisis ekonomi atas hukum pidana adalah prinsip rasionalitas dan prinsip efisiensi.Analisisekonomi atas hukum bekerja dengan menggunakan metode ilmu ekonomi sebagai kerangka teoritis guna menganalisis aturan dan hukum yang digunakan pada kalangan masyarakat tertentu ${ }^{12}$.

Steven Shavell, dalam tulisannya berjudul Economic Analysis of Lawmenyatakan bahwa dalam rangka pendekatan ekonomi untuk menganalisa hukum maka terdapat dua pertanyaan pokok yakni: pertanyaan deskriptif berkenaan dengan akibat dari aturan-aturan hukum terhadap perilaku dan hasilnya; dan pertanyaan evaluatif, berkenaan dengan kehendak masyarakat mengenai dampak dari aturan hukum. Dalam menjawab pertanyaan-pertanyaan tersebut, metode yang digunakan adalah analisa ekonomi secara umum. Setiap orang atau badan diasumsikan bersifat rasional kedepan dan kerangka ekonomi kesejahteraan digunakan untuk menentukan apa yang sebetulnya menjadi kehendak masyarakat.

Dari beberapa macam sanksi pidana pokok yang terdapat dalam Pasal 10 KUHP, jika diselaraskan dengan prinsip efisiensi sebagaimana dalam kajian ekonomi terhadap penegakan hukum untuk tindak pidana white collar crime, maka sanksi pidana denda dan sanksi hukuman mati bisa dikatakan memiliki ciri efisiensi tersebut. ${ }^{13}$

Adapun sanksi pidana denda (fines), yang merupakan bentuk sanksi keuangan, adalah pidana yang efisien karena penjatuhannya tidak memerlukan biaya apapun. Negara sendiri tidak mengeluarkan biaya apapun ketika menjatuhkan sanksi pidana denda.Pidana denda dianggap sangat efisien dalam mencegah pelaku untuk melakukan kejahatan.Selain pidana denda, pidana mati juga merupakan bentuk pidana yang efisien karena tidak memerlukan ongkos apapun.Tetapi pidana mati baru bisa dikatakan efisien jika jarak antara penjatuhan pidana terhadap pelaku dengan pelaksaan pidana mati itu tidak terlalu lama (singkat). Artinya, jika jarak tersebut lama (antara vonis dan eksekusi) maka tidak bisa dikatakan efisien mengingat narapidana yang dijatuhkan vonis mati tersebut akan menunggu eksekusi di dalam penjara ${ }^{14}$.

Undang-Undang No. 20 Tahun 2001 tentang Pemberantasan Tindak Pidana Korupsi (Tipikor), misalnya, selain pidana pokok berupa pidana penjara dan denda, juga mengancam terdakwa korupsi dengan pidana tambahan. Pasal 34 huruf c menyebutkan salah satu bentuk pidana tambahan tersebut adalah berupa uangpengganti. Konsep yang kurang lebih sama dengan sedikit modifikasi dianut oleh UU penggantinya yakni UU No. 31 Tahun 1999 yang kemudian direvisi lagi menjadi UU No. 20 Tahun 2001.

Pertimbangan lain yang melatarbelakangi munculnya konsep pidana uang pengganti adalah dalam rangka mengembalikan uang negara yang melayang akibat suatu tipikor. Pemikiran ini sejalan dengan definisi tipikor. Menurut UU, salah satu unsur tipikor adalah adanya tindakan yang ,merugikan keuangan negara ${ }^{e}$. Dengan adanya unsur ini, maka setiap terjadi suatu tipikor pasti akan menimbulkan kerugian pada keuangan negara.

\footnotetext{
${ }^{12}$ Mahrus Ali. Hukum Pidana Korupsi Di Indonesia.(Yogyakarta : UII Press 2011) hlm. 11

${ }^{13} \mathrm{Al}$ ' Adl, Volume VI Nomor 12, Juli-Desember 2014 dlam Yati Nurhayati,ANALISIS EKONOMI TERHADAP HUKUM DALAM PENANGGULANGAN TINDAK PIDANA KORUPSI, HIm. 74-75

${ }^{14}$ Op.Cit., Jurnal Pendidikan.... Hlm. 3
} 
Oleh karena itu, adalah suatu hal yang wajar apabila pemerintahkemudian menerapkan sebuah kebijakan dalam hal ini tertuang dalam produk perundang-undangan dalam mengupayakan kembalinya uang negara yang hilang akibat tipikor.

Dalam UU No 31 Tahun 1999 jo. UU No 20 Tahun 2001, bentuk perbuatan 'Korup' atau korupsi dikelompokkan menjadi 7 bagian, yaitu:

1. Kerugian Keuangan Negara

2. Suap-menyuap

3. Penggelapan dalam jabatan

4. Pemerasan

5. Perbuatan curang

6. Benturan kepentingan dalam pengadaan

7. Gratifikasi.

Dari pngelompokan diatas, perlu kita ketahui kiranya apa yang di maksud dengan tindak pidana korupsi, berdasarkan Pasal 2 ayat 1 Undang-undang Nomor 31 tahun 1999 tentang Pemberantasan Tindak Pidana Korupsi adalah "Setiap orang yang secara melawan hukum melakukan perbuatan memperkaya diri sendiri atau orang lain atau suatu korporasi yang dapat merugikan keuangan Negara atau pereknomian Negara”. Dari penjelasan tersebut dapat di tarik unsur dalam penetapan pertanggngjawaba pidana daam tindak pidana korupsi; yaitu:

1. Setiap Orang

Kata setiap orang mempunyai arti sebagai subjek hukum yang jika diuraikan akan menjadi orang atau badan hukum yang mempunyai hak dan kewajiban yang dapat dimintai pertanggungjwaban atas perbuatanya.

2. Melawan Hukum.

Adapun yang dimaksud unsur ini mencakup perbuatan melawan hukum dalam arti formil maupun materiil yakni meskipun perbuatan tersebut tidak diatur dalam peraturan perundang-undangan, namun apabila perbuatan tersebut dianggap tercela karena tidak sesuai dengan rasa keadilan atau norma-norma kehidupan sosial dalam masyarakat.

3. Memperkaya diri sendiri atau orang lain atau suatu korporasi.

Yang dimaksud dengan unsur iniadalah semua jenis tindak pidana yang tercantum dalam perbuatan yang di larang dalam Undang-undang Nomor 31 tahun 1999 Tentang Pemberantasan Tindak Pidana Korupsi dilakuakan baik secara sadar maupun tidak sadar digunakan untuk kepentingan diri sendiri atau suatu kelompok.

4. Merugikan Keuangan Negara atau Perekonomian Negara.

Dalam ha ini yang menjadi pihak korban adalah Negara, namum secara sadar atau tidak tindak pidana korupsi ini sebenarnya merugikan seluruh rakyat yang ada di suatu Negara tersebut.

Peranan Badan Pemeriksa Keuangan (BPK) dalam kasus tindak pidana korupsi tersebut sangat besar.Kasus-kasus ini sangat sulitterungkap ke permukaan jika BPK tidak menemukan kerugian negara.Menurut pasal 8 ayat (4) Undang- undang No 15 Tahun 2006 tentang Badan Pemeriksa Keuangan, Hasil dari Audit Badan Pemeriksa Keuangan merupakan dasar penyidikan bagi pejabat penyidik sesuai dengan peraturan perundang-undangan yang berlaku (KUHAP) ${ }^{15}$ Analisis biaya terhadap hasil-hasil yang diperoleh dalam hubungannya dengan tujuan-tujuan yang ingin dicapai harus diperhatikan dalam penanggulangan tindak pidana korupsi artinya apakah hasil yang ingin dicapai memadai dengan biaya yang dikeluarkan.

\section{Contoh Kasus- Kasus yang Inkracht dengan mempertimbangkan Analisa Ekonomi atas Hukum} Tabel 1

Pidana Uang Pengganti dalam Beberapa Kasus Korupsi (berdasarkan putusan inkracht dan in absentia)

\begin{tabular}{|c|c|c|c|}
\hline & Terpidana & Kerugian Negara & Uang Pengganti \\
\hline & $\begin{array}{l}\text { Hendra Raharja } \\
\text { Korupsi BLBI Bank BHS }\end{array}$ & $\begin{array}{l}\text { Rp.305.345.074.000 } \\
\text { AS } \$ 2.304 .809,36\end{array}$ & Rp. 1.9 Triliun \\
\hline
\end{tabular}

${ }^{15} \mathrm{Al}$ ' Adl, Volume VI Nomor 12, Juli-Desember 2014 dlam Yati Nurhayati,ANALISIS EKONOMI TERHADAP HUKUM DALAM PENANGGULANGAN TINDAK PIDANA KORUPSI, HIm. 74-75 


\section{Dedy Syaputra}

2. Bob Hasan

Korupsi Pemotretan dan Pemetaan Hutan lindung

Samadikun Hartono

Korupsi BLBI Bank Modern

Sudjiono Timan

Korupsi BPUI

Huzrin Hood

Korupsi APBD Kepulauan Riau (Kepri) Tahun 2001 dan 2002

Bambang Sutrisno dan Adrian Kiki Aryawan

Korupsi BLBI Bank Surya.

Eddy Tansil

Korupsi BAPINDO

Asriadi,

Korupsi di bidang pajak

Iwan Zulkarnaen

Korupsi Bidang pajak

$\begin{array}{ll}\text { AS\$243 juta } & \text { Rp1,9 triliun } \\ \text { Rp80.742.270.581 } & \text { Rp169 miliar } \\ \text { Rp1,29 trilun } & \text { Rp369 miliar } \\ \text { Rp3,4 miliar } & \text { Rp3,4 miliar } \\ & \\ \text { Rp1, 5 triliun } & \text { Rp1, 5 triliun } \\ \text { Rp1,3 triliun } & \begin{array}{l}\text { uang pengganti Rp500 } \\ \text { miliar dan membayar } \\ \text { kerugian negara Rp1,3 } \\ \text { triliu miliar } \\ \text { Rp13 m40 miliar }\end{array} \\ \text { Rp40 miliar } & \text { Rp27 miliar }\end{array}$

\section{AS\$243 juta}

Rp40 miliar
Rp1,9 triliun

Rp169 miliar

milia

*Sumber ICW

\section{SIMPULAN}

Pemikiran mengenai Analisis ekonomi terhadap hukum dilatar belakangi oleh mazhab utilitarianisme yang di pelopori oleh Jeremy Bantham (1789) pemikiran ini tersebar dalam tulisan-tulisan berupa analisis atas hukum pidana dan penegakannya, analisis mengenai hak milik dan substantial treatment yang membahas tentang proses-prose hukum. Namun pemikiran ini terlambat sampai tahun 1960 an dan muncul kembali pada tahun 1990an.

Steven Shavell, dalam tulisannya berjudul Economic Analysis of Lawmenyatakan bahwa dalam rangka pendekatan ekonomi untuk menganalisa hukum maka terdapat dua pertanyaan pokok yakni: pertanyaan deskriptif berkenaan dengan akibat dari aturan-aturan hukum terhadap perilaku dan hasilnya; dan pertanyaan evaluative.

Di Indonesia sendiri penerapan analisa ekonomi atas hukum dalam pertanggujawaan pidana korupsi dilakuakan dalam perhitungan kerugian Negara, serta dalam penerapan sanksi dalam pidana korupsi.

\section{DAFTAR PUSTAKA}

\section{Buku}

Ady Irawan. Jurnal Pendidikan Ips, Vol. 7. No. 1, Januari-Juni 2017, Analisis Ekonomi Terhadap Hukum Dalam Kebijakan Penegakan Hukum Pidana Di Indonesia

Indrianto Seno Aji, Antar Penegak Hukum Dan Korupsi Sistematik Sebagai Kendala Penegak Hukum Di Indonesia,(Ui, Femm, Jakarta. 2007)

Mahrus Ali. Hukum Pidana Korupsi Di Indonesia.(Yogyakarta : Uii Press 2011)

Al' Adl, Volume Vi Nomor 12, Juli-Desember 2014 Dlam Yati Nurhayati,Analisis Ekonomi Terhadap Hukum Dalam Penanggulangan Tindak Pidana Korupsi

Tresya, Peran Bpom Dalam Melakukan Pengawasan Terhadap Pangan Tanpa Izin Edar, Jurnal Wajah Hukum, Volume 2 Nomor 2 (Oktober 2018)

\section{Perundang-Undangan}

Kumpulan Kitab Undang-undang hukum (KUHPerdata, KUHPidana, KUHAP). Cetakan II Tahun 2016. Wacana Intelectual

Undang-undang No. 20 tahun 2001 tentang Tindak Pidana Korupsi

Undang- undang No 15 Tahun 2006 tentang Badan Pemeriksa Keuangan 